\title{
Role of $\alpha$-amino-3-hydroxy-5-methylisoxazole-4-propionic acid receptors in the control of prolactin, growth hormone and gonadotropin secretion in prepubertal rats
}

\author{
L C González, L Pinilla, M Tena-Sempere and E Aguilar
}

Department of Physiology, University of Córdoba, 14004 Córdoba, Spain

(Requests for offprints should be addressed to E Aguilar, Department of Physiology, University of Córdoba, Avda Menéndez Pidal s/n, 14004 Córdoba, Spain)

\begin{abstract}
Excitatory amino acids, such as glutamate, constitute a major transmitter system in the control of hypothalamicpituitary secretion. Different subtypes of glutamate receptors, such as NMDA (N-methyl-D-aspartic acid) and KA (kainate) receptors, are involved in the control of anterior pituitary secretion. Other receptor subtypes, such as AMPA (activated by $\alpha$-amino-3-hydroxy-5methylisoxazole-4-propionic acid) and metabotropic receptors, have been identified, although their role in the control of neuroendocrine function remains largely unknown. Recent reports have demonstrated the involvement of AMPA receptors in the control of the steroidinduced luteinizing hormone (LH) surge in female and growth hormone $(\mathrm{GH})$ secretion in male rats. The aim of this study was to assess the potential role of AMPA receptors in the control of $\mathrm{GH}$, prolactin (PRL), $\mathrm{LH}$ and follicle-stimulating hormone (FSH) secretion in prepubertal 23-day-old rats. To this end, prepubertal female rats were injected with AMPA $(2.5$ or $5 \mathrm{mg} / \mathrm{kg}$ i.p. $)$ or the antagonist of AMPA receptors 1,2,3,4-tetrahydro-6-nitro2,3-dioxo-benzo (f) quinoxaline-7-sulfonamide (NBQX; 0.25 or $0.50 \mathrm{mg} / \mathrm{kg}$ i.p.). Serum LH and FSH concentrations and hypothalamic LH-releasing hormone (LHRH) content remained unchanged after AMPA or NBQX administration. In contrast, serum PRL levels significantly decreased 15, 30 and 60 min after i.p. administration of AMPA and increased $120 \mathrm{~min}$ after NBQX treatment, whereas serum GH levels increased after AMPA treatment and decreased after NBQX administration. Considering that AMPA has been shown to activate a subset of kainate receptors, its effects were compared with those elicited by $2.5 \mathrm{mg} / \mathrm{kg} \mathrm{KA}$ in prepubertal female rats. At this age, however, KA was unable to reproduce the effects of AMPA on PRL and GH secretion, thus suggesting that the actions observed after AMPA administration were carried out specifically through AMPA receptors. In addition, as the effects of AMPA on LH secretion in adult females have been proved to be
\end{abstract}

steroid-dependent, the effects of AMPA $(2.5 \mathrm{mg} / \mathrm{kg})$ and NBQX $(0.5 \mathrm{mg} / \mathrm{kg})$ were tested in prepubertal animals with different gonadal backgrounds, i.e. intact males, and intact and ovariectomized (OVX) females. The effects of AMPA in prepubertal females appeared to be modulated by ovarian secretion, as the inhibition of PRL secretion disappeared and LH secretion was partially suppressed by AMPA in OVX animals whereas the stimulatory effect on GH release was enhanced by ovariectomy. Furthermore, in male rats, AMPA administration significantly decreased PRL secretion and increased serum GH levels, the amplitude of the $\mathrm{GH}$ response being higher than in prepubertal females. To ascertain the pituitary component for the reported actions of AMPA, hemi-pituitaries of male rats were incubated in the presence of AMPA $\left(10^{-8}-10^{-6} \mathrm{M}\right)$. The results obtained showed no effect of AMPA on PRL, GH and gonadotropin secretion in vitro. Finally, we investigated the involvement of the dopaminergic (DA) system in the inhibitory action of AMPA on PRL secretion. Pre-treatment of prepubertal female rats with a dopamine receptor antagonist (domperidone: $1 \mathrm{mg} / \mathrm{kg}$ ) resulted in the blockage of AMPA-mediated inhibition of PRL secretion, thus suggesting that this action is probably mediated by an increase in DA activity. In conclusion, we provide evidence for the physiological role of AMPA receptors in the control of PRL and GH secretion in prepubertal rats. In contrast, our data cast doubts on the involvement of AMPA receptors in the regulation of gonadotropin secretion at this age. The effects of AMPA reported herein were not mediated through activation of kainate receptors and were probably exerted at the hypothalamic or suprahypothalamic levels. In addition, we show that ovarian secretion actively modulates the effects of AMPA receptor activation on anterior pituitary secretion in prepubertal female rats.

Journal of Endocrinology (1999) 162, 417-424 


\section{Introduction}

Excitatory amino acids (EAAs) are the major activating transmitters in the brain (van den Pol et al. 1990). The actions of EAAs are mediated by different post-synaptic receptors which include N-methyl-D-aspartate (NMDA) receptors, kainate (KA) receptors, 2-amino-3-hydroxy-5 methyl isoxazole-4-propionic acid (AMPA) receptors, amino-4-phosphobutyric acid (L-AP4) receptors and metabotropic receptors (Collingridge \& Watkins 1994, Wenthold \& Petraglia 1998).

Recently, agonists and antagonists of AMPA receptors have been developed and activation of AMPA receptors has been shown to stimulate gonadotropin-releasing hormone $(\mathrm{GnRH})$ release from rat hypothalamic fragments and from immortalized GnRH neurons (Donoso et al. 1990, Spergel et al. 1994, Zuo et al. 1996). Furthermore, the involvement of AMPA receptors in the stimulatory pathways responsible for the control of luteinizing hormone ( $\mathrm{LH})$ secretion has been demonstrated in a variety of species (López et al. 1990, Ebling et al. 1993, Kumar et al. 1993, Ping et al. 1997). In addition, evidence for a stimulatory role of AMPA receptors in the regulation of growth hormone $(\mathrm{GH})$ secretion in male rats has been presented recently (González et al. 1999).

The present experiments were carried out to assess the role, if any, of AMPA receptors in the regulation of anterior pituitary secretion in prepubertal rats. Prepubertal animals were selected for analysis as, at this age, pulsatile secretion of anterior pituitary hormones is not fully established (Gabriel et al. 1992, Ojeda \& Urbanski 1994), thus allowing a high rate of homogeneity in basal hormone secretion (our personal observations). In addition, solid evidence indicates that the physiological role of several subtypes of glutamate receptors in the control of anterior pituitary secretion is maximally expressed in immature animals, and declines with age (Bourguignon et al. 1992, Pinilla et al. 1995b, 1996a). Moreover, the crucial role of glutamate receptors subtypes, such as NMDA receptors, in the onset of puberty is well proven (MacDonald \& Wilkinson 1990, Urbanski \& Ojeda 1990). To address these questions, the effects of AMPA and 1,2,3,4tetrahydro-6-nitro-2,3-dioxo-benzo (f) quinoxaline7 -sulfonamide (NBQX) (agonist and antagonist of AMPA receptors respectively) on serum follicle-stimulating hormone $(\mathrm{FSH}), \mathrm{LH}$, prolactin $(\mathrm{PRL})$ and $\mathrm{GH}$ concentrations were tested in prepubertal females, and compared with those observed after KA administration. In addition, as ovarian secretion has been suggested to modulate the functional role of AMPA receptors in the control of LH secretion in adult female rats (Ping et al. 1997), the effects of AMPA and NBQX were evaluated in prepubertal animals with different gonadal backgrounds, i.e. intact males, and intact and ovariectomized females. Finally, the involvement of dopamine (DA) in the action of AMPA on
PRL secretion was investigated. Our results demonstrate that activation of AMPA receptors stimulates GH release, inhibits PRL secretion and does not change gonadotropin release in prepubertal female rats. These effects appeared to be modulated by ovarian secretion at this age. In addition, we provide data suggesting the involvement of DA in AMPA-induced inhibition of PRL secretion.

\section{Materials and Methods}

\section{Animals and drugs}

Wistar rats born in our laboratory were maintained under controlled conditions of light $(12 \mathrm{~h}$ light: $12 \mathrm{~h}$ darkness, lights on at $0700 \mathrm{~h})$ and temperature $\left(22^{\circ} \mathrm{C}\right)$ with free access to pelleted food (Pacsa Sanders, Seville, Spain) and tap water. On day 1 of life each dam was left with eight pups. ( \pm )- $\alpha$-amino-3-hydroxy-5-methylisoxazole4-propionic acid (AMPA, an agonist of AMPA receptors), 1,2,3,4-tetrahydro-6-nitro-2,3-dioxo-benzo (f) quinoxaline-7-sulfonamide (NBQX, an antagonist of AMPA receptors) and domperidone (an antagonist of dopamine receptors) were purchased from Research Biochemicals International (Natick, MA, USA). AMPA and NBQX were dissolved initially in a few drops of dimethylsulfoxide (DMSO), and domperidone was dissolved initially in a few drops of methanol. Thereafter, the drugs were dissolved in saline up to the working concentration.

\section{Experimental designs}

In experiment 1, 23-day-old female Wistar rats were killed by decapitation 15, 30 and 60 min after i.p. injection of AMPA $(2.5$ or $5 \mathrm{mg} / \mathrm{kg})$ or vehicle and 60 and $120 \mathrm{~min}$ after i.p. injection of NBQX $(0 \cdot 25$ and $0.50 \mathrm{mg} / \mathrm{kg})$ or vehicle. The doses and route of administration as well as the time-points for hormone measurements were selected based on our previous work, as this protocol has proved to be effective in unravelling the physiological role of AMPA receptors in the control of $\mathrm{GH}$ secretion in prepubertal male rats (González et al. 1999). In keeping with our previous observations, no effects on rat behavior were observed at the doses selected. All experiments were started at $1000 \mathrm{~h}$. Special precautions were taken to avoid any stressing influences (e.g. all animals were handled daily for a week before the experiment and killed by the same person, the different drugs being injected at random). Upon decapitation, trunk blood from each animal was collected in polystyrene tubes, and the hypothalamus was dissected and frozen immediately after extraction. Blood samples were left to clot overnight at $4{ }^{\circ} \mathrm{C}$, and sera were separated by centrifugation $(2800 \mathrm{~g}$ for $20 \mathrm{~min}$ ) and stored at $-20{ }^{\circ} \mathrm{C}$ until used for hormone measurements.

It has been reported previously that AMPA can activate a subset of kainate receptors (Brann \& Mahesh 1997). 
Experiment 2 was designed to evaluate to what extent the observed effects of AMPA on anterior pituitary secretion could be attributable to activation of KA receptors. To this end, 23-day-old prepubertal female rats were decapitated $15 \mathrm{~min}$ after i.p. injection of vehicle or KA $(2.5 \mathrm{mg} / \mathrm{kg})$, and the effects compared with those obtained in experiment 1 .

In experiment 3 , we aimed to ascertain whether, as suggested for LH secretion in adult female rats (Ping et al. 1997), the role of AMPA receptors in the control of anterior pituitary secretion in prepubertal animals is modulated by gonadal secretion. To this end, the effects of AMPA and NBQX were evaluated in prepubertal animals with different gonadal backgrounds, i.e. intact and ovariectomized females and intact males. Female rats were ovariectomized (OVX) or sham-OVX on day 15 of age and decapitated on day 23, 15 min after vehicle or AMPA $(2.5 \mathrm{mg} / \mathrm{kg})$ administration and $60 \mathrm{~min}$ after vehicle or NBQX $(0 \cdot 5 \mathrm{mg} / \mathrm{kg})$ administration. In addition, 23-dayold prepubertal intact males were decapitated after AMPA $(2.5 \mathrm{mg} / \mathrm{kg},-15 \mathrm{~min})$ and NBQX $(0.5 \mathrm{mg} / \mathrm{kg}$, $-60 \mathrm{~min})$ administration.

In experiment 4, we investigated whether the observed effects of AMPA on anterior pituitary hormone secretion are exerted, at least partially, at the pituitary level. Prepubertal 23-day-old males were killed by decapitation, and their anterior pituitaries were immediately removed, dissected free of the posterior pituitary lobe, and halved. Hemi-pituitaries were preincubated for $1 \mathrm{~h}$ in $1 \mathrm{ml}$ gentamicin-supplemented DMEM-F12 medium in a Dubnoff shaker $(60$ cycles $/ \mathrm{min})$ at $37^{\circ} \mathrm{C}$ under an atmosphere of $5 \% \mathrm{CO}_{2}-95 \% \mathrm{O}_{2}$. After preincubation, the media were replaced either by fresh medium or medium containing increasing doses of AMPA $\left(10^{-8}-10^{-6} \mathrm{M}\right)$. After $60 \mathrm{~min}$, aliquots from the incubation media were taken for hormone measurements, as described below.

In experiment 5, the potential involvement of dopamine in the observed inhibition of PRL secretion by AMPA was investigated. For this purpose, 23-day-old female rats were pre-treated with vehicle or domperidone $(1 \mathrm{mg} / \mathrm{kg}$ at $-60 \mathrm{~min})$ and killed $15 \mathrm{~min}$ after injection of vehicle or AMPA $(2.5 \mathrm{mg} / \mathrm{kg})$.

All experiments were approved by the Córdoba University Ethical Committee for animal experimentation, and were conducted in accordance with the European Union normative for care and use of experimental animals.

\section{Hormone assays}

LH, FSH, PRL and GH levels were measured by specific RIAs using kits supplied by the NIDDK (Bethesda, MD, USA), and hormone concentrations were expressed using reference preparation (RP) LH-2, FSH-RP-2, PRLRP-3 and GH-RP-2 as standards. All samples were measured in duplicate. Intra-assay coefficients of variation were below 7\% and interassay coefficients of variation were below $11 \%$, all samples from each experiment being measured in the same assay. The sensitivities of the assays were 7·5, 20, 5 and $10 \mathrm{pg} /$ tube for FSH, LH, GH and PRL determinations respectively. LH releasing hormone (LHRH) content in the mediobasal hypothalamus (MBH) was measured as previously described (Pinilla et al. 1995a). Briefly, hypothalamic fragments encompassing the $\mathrm{MBH}$, delimited by the hypothalamic fissures, the optic chiasm and the mamillary bodies, were dissected under a stereomicroscope by a horizontal cut of about $2 \mathrm{~mm}$ depth. Tissue samples were homogenized in $0.1 \mathrm{M}$ acetic acid and measured in duplicate by RIA using the LHRH antibody HU-60 (kindly donated by Dr H F Urbanski, Neuroscience Division, Oregon Regional Primate Research Center, Beaverton, OR, USA) and ${ }^{125}$-labeled synthetic LHRH (Peninsula Laboratories, Belmont, CA, USA) as tracer. The assay buffer consisted of $0.01 \mathrm{M}$ sodium phosphate, $0.145 \mathrm{M} \mathrm{NaCl}, 0.032 \mathrm{M}$ EDTA, $0 \cdot 0001 \mathrm{M}$ sodium azide and $0 \cdot 25 \%$ human serum albumin ( $\mathrm{pH} 7 \cdot 4)$. All samples were run in the same assay. The intra-assay coefficient of variation was $9 \%$ and the sensitivity of the assay was $10 \mathrm{pg} / \mathrm{ml}$.

\section{Statistics}

Data are expressed as means \pm S.E.M. (8-12 animals per group). Differences between groups were determined by one- or two-way analysis of variance (ANOVA) followed by Tukey's test.

\section{Results}

Effects of AMPA and NBQX in intact 23-day-old female rats

Growth hormone Serum GH concentrations significantly increased $15 \mathrm{~min}$ after administration of 2.5 or $5 \mathrm{mg} / \mathrm{kg}$ AMPA, whereas at $30 \mathrm{~min}$, only the higher dose induced a significant effect on GH release (Fig. 1). NBQX $(0.25 \mathrm{mg} / \mathrm{kg})$ induced a decrease in serum GH concentrations at $60 \mathrm{~min}$, while at $120 \mathrm{~min}$ the data showed high variability and the observed differences were not significant (Fig. 2, upper panel).

Prolactin Serum PRL concentrations decreased significantly $15 \mathrm{~min}$ after administration of 2.5 and $5 \mathrm{mg} / \mathrm{kg}$ AMPA, while only the dose of $5 \mathrm{mg} / \mathrm{kg}$ was effective $60 \mathrm{~min}$ after administration (Fig. 1). Serum PRL concentrations increased $120 \mathrm{~min}$ after administration of $0.5 \mathrm{mg} / \mathrm{kg}$ NBQX (Fig. 2, lower panel).

Gonadotropins and LHRH Serum LH, FSH and hypothalamic LHRH concentrations remained unchanged 15,30 and $60 \mathrm{~min}$ after administration of 2.5 or $5 \cdot 0 \mathrm{mg} / \mathrm{kg}$ 

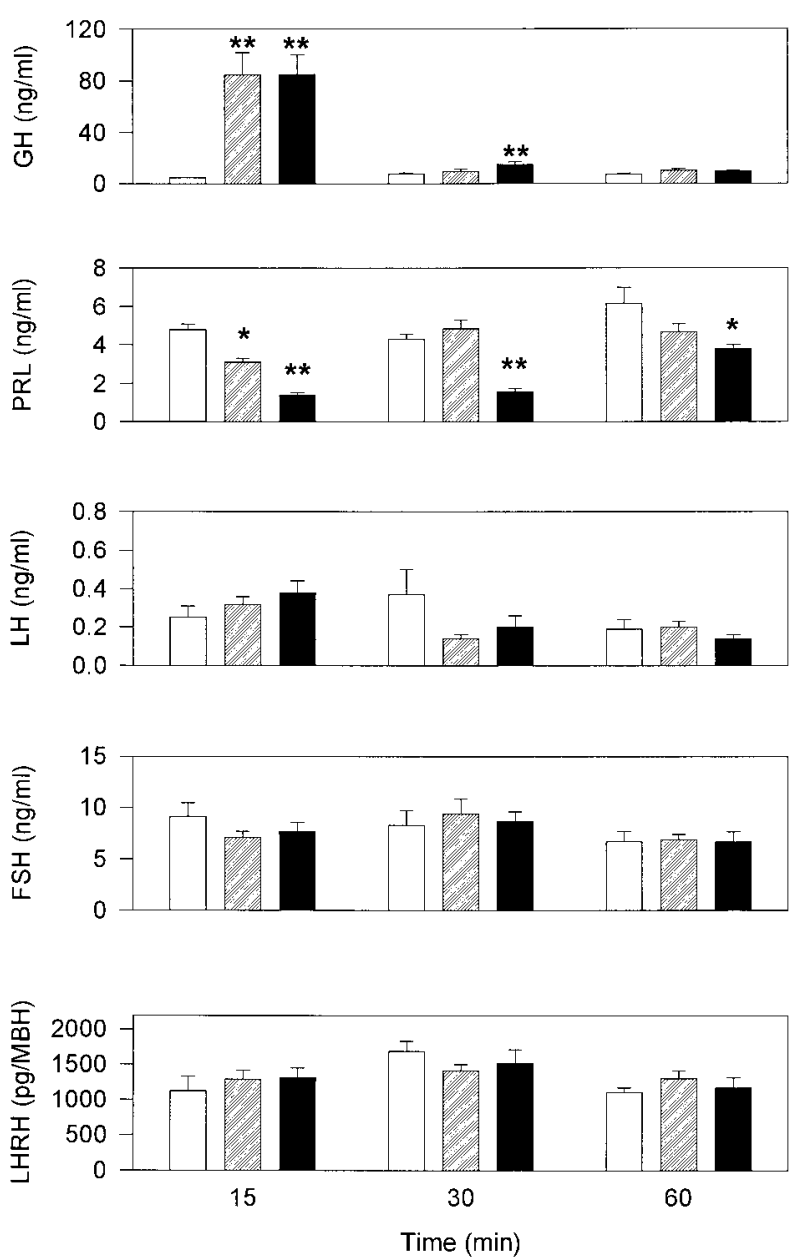

Figure 1 Serum GH, PRL, LH and FSH concentrations ( $\mathrm{ng} / \mathrm{ml})$ and hypothalamic LHRH content $(\mathrm{pg} / \mathrm{MBH})$ in 23-day-old female rats at different times after administration of AMPA (hatched bars: $2.5 \mathrm{mg} / \mathrm{kg}$; solid bars: $5 \mathrm{mg} / \mathrm{kg}$ ) or vehicle (open bars). Values are given as means \pm S.E.M. $\left(10-12\right.$ animals/group). ${ }^{*} P<0 \cdot 05,{ }^{*} P<0 \cdot 01$ vs vehicle-injected group (ANOVA followed by Tukey's test).

AMPA (Fig. 1) and after NBQX administration (data not shown).

Effects of $K A$ in intact 23-day-old female rats

Serum levels of GH, PRL, LH and FSH were not significantly altered $15 \mathrm{~min}$ after administration of $2.5 \mathrm{mg} / \mathrm{kg} \mathrm{KA}$ to 23 -day-old females (Table 1 ).

\section{Effects of AMPA and NBQX in 23-day-old OVX female} and intact male rats

Growth hormone The stimulatory effect of AMPA $(2.5 \mathrm{mg} / \mathrm{kg})$ was significantly higher in prepubertal males than in intact females. The effect of AMPA was markedly enhanced after ovariectomy and was similar to that
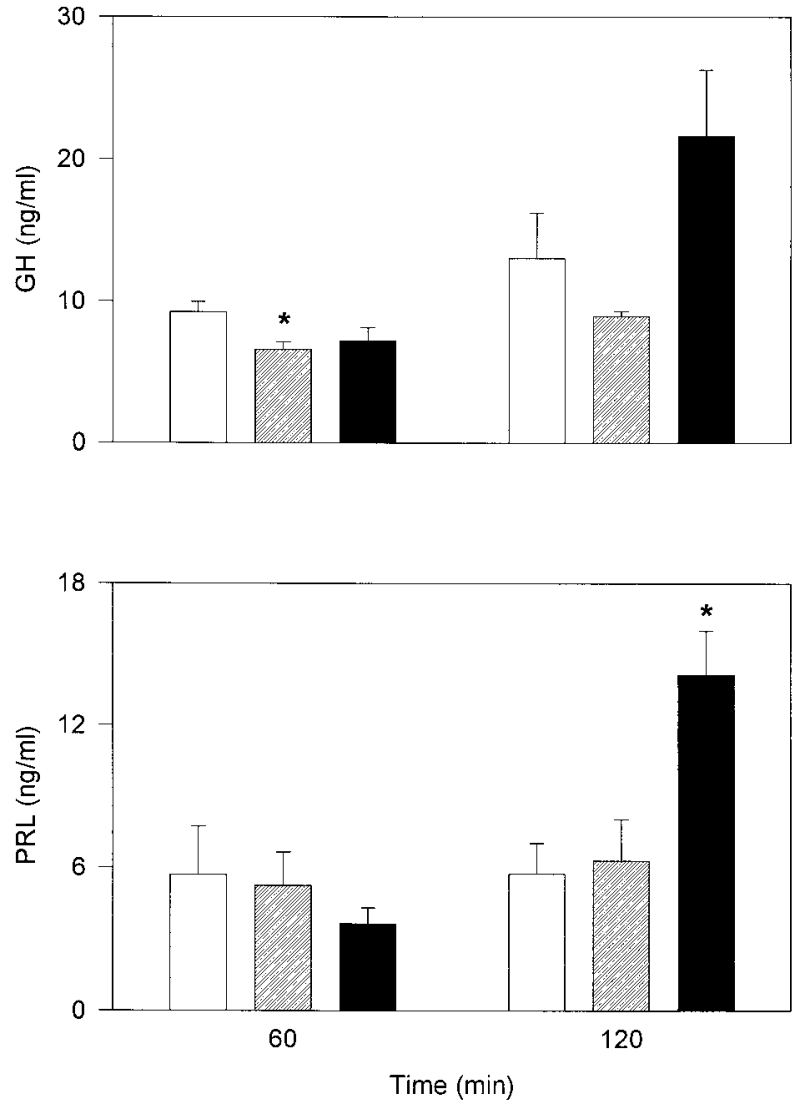

Figure 2 Serum GH and PRL concentrations in 23-day-old female rats 60 and 120 min after i.p. administration of vehicle (open bars) or NBQX (hatched bars: $0.25 \mathrm{mg} / \mathrm{kg}$; solid bars: $0.5 \mathrm{mg} / \mathrm{kg}$ ). Values are given as means \pm S.E.M. ( 10 animals per group). ${ }^{*} P<0.05$ vs vehicle-injected group (ANOVA followed by Tukey's test).

observed in intact males (Fig. 3). Serum GH levels were similar in OVX females $60 \mathrm{~min}$ after administration of vehicle $(8.97 \pm 2.17 \mathrm{ng} / \mathrm{ml})$ or $0.5 \mathrm{mg} / \mathrm{kg}$ NBQX $(10 \cdot 32 \pm 1 \cdot 49 \mathrm{ng} / \mathrm{ml})$.

Prolactin In intact males, $2.5 \mathrm{mg} / \mathrm{kg}$ AMPA inhibited PRL secretion $15 \mathrm{~min}$ after administration, and the effect was similar to that observed in prepubertal females (Fig. 3). In OVX females, serum PRL levels were similar $15 \mathrm{~min}$ after administration of vehicle or $2.5 \mathrm{mg} / \mathrm{kg}$ AMPA (Fig. 3) and $60 \mathrm{~min}$ after administration of vehicle $(5 \cdot 16 \pm 0.56 \mathrm{ng} / \mathrm{ml})$ or $0.5 \mathrm{mg} / \mathrm{kg} \quad \mathrm{NBQX}$ $(6 \cdot 47 \pm 1 \cdot 13 \mathrm{ng} / \mathrm{ml})$.

Gonadotropins Administration of AMPA $(2.5 \mathrm{mg} / \mathrm{kg})$ to intact males and females did not change serum concentrations of $\mathrm{LH}$ and FSH. In contrast, AMPA inhibited LH secretion in OVX females (Fig. 3). Moreover, serum LH levels in OVX females were higher $(P<0 \cdot 01) 60$ min after administration of NBQX $(21.36 \pm 2.75 \mathrm{ng} / \mathrm{ml})$ than after vehicle injection $(14.81 \pm 1.52 \mathrm{ng} / \mathrm{ml})$. 
Table 1 Serum GH, PRL, LH and FSH concentrations ( $\mathrm{ng} / \mathrm{ml})$ in intact females treated with kainic acid $(2 \cdot 5 \mathrm{mg} / \mathrm{kg}$ at $-15 \mathrm{~min})$. Values are given as means \pm S.E.M. with number of animals in parentheses

\begin{tabular}{|c|c|c|c|c|}
\hline \multirow[b]{2}{*}{ Treatment } & GH & PRL & LH & FSH \\
\hline & & & & \\
\hline Vehicle & $8 \cdot 83 \pm 2.68(6)$ & $2 \cdot 83 \pm 0 \cdot 38(7)$ & $0.25 \pm 0.09(7)$ & $11 \cdot 06 \pm 1 \cdot 25$ \\
\hline Kainic acid & $7 \cdot 36 \pm 1 \cdot 83$ & $2 \cdot 17 \pm 0 \cdot 20$ & $0 \cdot 84 \pm 0.28$ & $8 \cdot 43 \pm 1 \cdot 32$ \\
\hline
\end{tabular}

Effects of AMPA on hormone secretion by hemi-pituitaries in vitro

Incubation of hemi-pituitaries from prepubertal male rats in the presence of AMPA did not induce significant modifications in the pattern of basal secretion of GH, PRL, LH or FSH (Fig. 4).
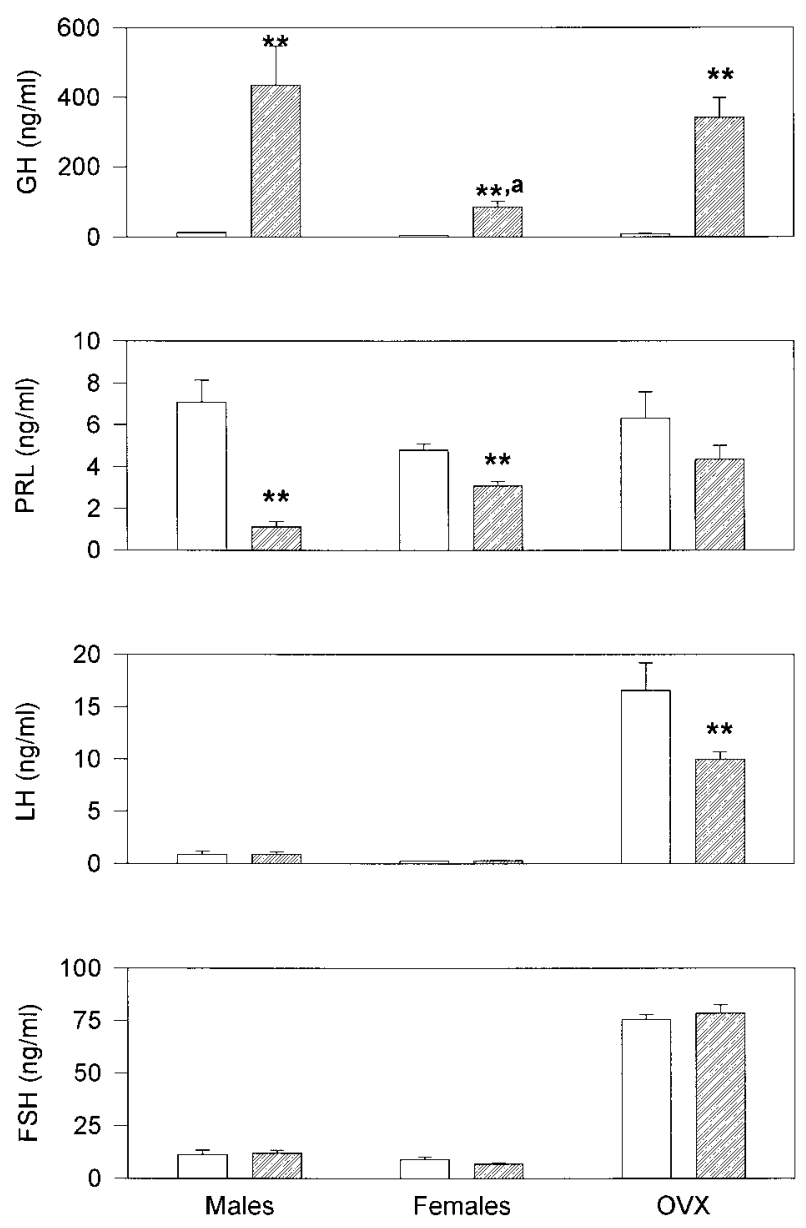

Figure 3 Serum $\mathrm{GH}, \mathrm{PRL}, \mathrm{LH}$ and $\mathrm{FSH}$ concentrations $(\mathrm{ng} / \mathrm{ml})$ in 23-day-old intact males and intact and OVX females decapitated $15 \mathrm{~min}$ after administration of AMPA ( $2.5 \mathrm{mg} / \mathrm{kg}$ : hatched bars) or vehicle (open bars). Values are given as means \pm S.E.M. $(10-12$ animals/group). ${ }^{*} P<0 \cdot 01$ vs vehicle-injected group; a $P<0 \cdot 01 \mathrm{vs}$ males injected with AMPA (ANOVA followed by Tukey's test).
Effects of AMPA in domperidone pre-treated 23-day-old female rats

Domperidone elicited a clear increase in serum PRL concentrations and abolished the inhibitory effect of AMPA, which was only observed in animals pre-treated with vehicle (Table 2).
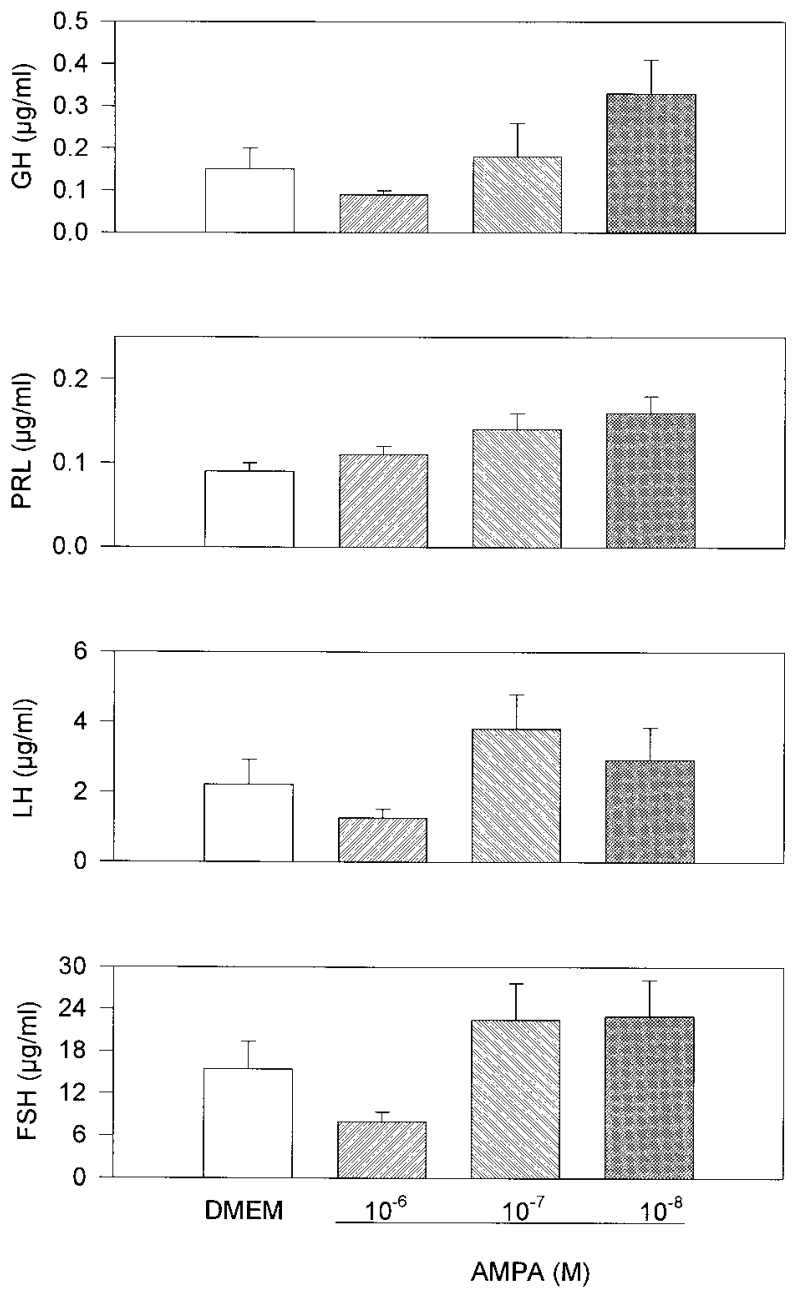

Figure $4 \mathrm{GH}, \mathrm{PRL}, \mathrm{LH}$ and $\mathrm{FSH}$ secretion by hemi-pituitaries $60 \mathrm{~min}$ after incubation in the presence DMEM alone or different doses of AMPA $\left(10^{-8}-10^{-6} \mathrm{M}\right)$. Values are given as means \pm S.E.M. (10-12 determinations/group). 
Table 2 Serum PRL concentrations $(\mathrm{ng} / \mathrm{ml})$ in intact females treated with domperidone $(1 \mathrm{mg} / \mathrm{kg}$ at $-60 \mathrm{~min})$ and AMPA $(2.5 \mathrm{mg} / \mathrm{kg}$ at $-15 \mathrm{~min})$. Values are given as means \pm S.E.M. with number of animals in parentheses

PRL

\section{Treatment}

Vehicle+vehicle

Vehicle + AMPA

Domperidone + vehicle

Domperidone+AMPA

$$
\begin{aligned}
7 \cdot 86 & \pm 0 \cdot 80(8)^{\mathrm{a}} \\
2 \cdot 41 & \pm 0 \cdot 24(10)^{\mathrm{b}} \\
62 \cdot 94 & \pm 4 \cdot 57(10)^{\mathrm{c}} \\
71 \cdot 59 & \pm 5 \cdot 87(9)^{\mathrm{c}}
\end{aligned}
$$

Groups marked with different superscript letters are significantly different $(P \leq 0 \cdot 01)$ (ANOVA followed by Tukey's test).

\section{Discussion}

Different neurotransmitters are involved in the control of hypothalamic neurons, which in turn regulate anterior pituitary secretion (for a review see Müller \& Nisticó 1989). EAAs are the major activating system in the brain (van den Pol et al. 1990) and in the last decade their role in the control of neuroendocrine function has been firmly established (for a review see Brann \& Mahesh 1992a,b, 1994, 1997). Different subtypes of glutamate receptors have been identified: NMDA receptors, kainate receptors, AMPA receptors and metabotropic receptors (Collingridge \& Watkins 1994, Wenthold \& Petraglia 1998). The biological roles of NMDA and KA receptors in the control of neuroendocrine function have been extensively analyzed (Brann \& Mahesh 1992a,b; 1994, 1997). In contrast, very few studies have been presented on the role of AMPA and metabotropic receptors in the regulation of pituitary secretion. However, recent evidence suggests that AMPA receptors are probably involved in the physiological control of LH in different species and physiological situations, as AMPA receptor activation stimulated LH secretion in estrogen-primed OVX female rats, male Syrian hamsters and rams (Ebling et al. 1993, Kumar et al. 1993, Ping et al. 1997), whereas AMPA administration was inhibitory to LH release in non-estrogen primed female rats (Ping et al. 1997). In addition, the involvement of AMPA receptors in the regulation of $\mathrm{GH}$ secretion in male rats has been demonstrated recently (González et al. 1999).

Our results clearly demonstrate that AMPA receptors participate in the control of anterior pituitary secretion in prepubertal female rats, and that the role of AMPA receptors at this age is modulated by ovarian secretion. The former is indicated by the significant changes induced in GH and PRL secretion after AMPA receptor activation or blockade, while the latter is indicated by the modification in the pattern of pituitary response to AMPA observed after ovariectomy.

Activation of AMPA receptors, as was the case for other subtypes of glutamate receptors (Mason et al. 1983, Acs et al. 1990, Pinilla et al. 1996a, Tena-Sempere et al. 1995,
1996), stimulated GH secretion in prepubertal rats. This fact, together with the decrease in serum GH concentrations observed $60 \mathrm{~min}$ after administration of $2.5 \mathrm{mg} / \mathrm{kg}$ NBQX, indicate that activation of AMPA receptors takes place as part of the physiological control of $\mathrm{GH}$ secretion at this age. It is noteworthy that GH responses observed after AMPA administration are not attributable to activation of kainate receptors, as KA was unable to mimic the effects of AMPA on GH secretion in 23-day-old female rats (Table 1). Interestingly, the pattern of GH response to KA administration changes sharply in the immature female rat, with a significant stimulatory effect in 30-day-old females but negligible responses between days 16 and 23 of age (Tena-Sempere et al. 1995, Pinilla et al. 1996a, and present results). The amplitude of GH response to AMPA was lower in prepubertal females than in males (Fig. 1), thus pointing to a more relevant role of AMPA receptors in the control of GH secretion in the prepubertal male rat. Such a difference was not observed after administration of NMDA or KA to prepubertal males and females (Pinilla et al. 1996a, Tena-Sempere et al. 1995, 1996). As a whole, these results strongly suggest that the role of different subtypes of EAA receptors in the control of GH secretion in prepubertal rats may be sexually dimorphic, AMPA receptors being more effective in males whereas NMDA and KA receptors were equally potent in both sexes. Since pituitary GH concentration and content are similar in prepubertal males and females (Birge et al. 1967), the reported sexual dimorphism suggests possible differences in the number and/or affinity of EAA receptor subtypes between prepubertal males and females.

The mechanisms whereby AMPA stimulates GH secretion are at present unknown. In theory, a stimulatory effect at the pituitary level, an increase in GHRH release or an inhibition of somatostatin secretion might be involved in the effects of AMPA. Among them, a pituitary effect of AMPA seems unlikely since, despite the presence of AMPA receptors in the pituitary gland (Kiyama et al. 1993, Meeker et al. 1994, Bhat et al. 1995, Villalobos et al. 1996), no significant effect of AMPA on in vitro GH was observed in prepubertal male rats. Evaluation of potential direct effects of AMPA on the release of GHRH and somatostatin by hypothalamic fragments will be our next step to elucidate the primary target for the stimulation of GH secretion after activation of AMPA receptors. However, on the basis of our present data, the possibility of a primary action of AMPA on other brain centres, e.g. outside the hypothalamus, cannot be ruled out.

In addition to the effects on $\mathrm{GH}$ secretion, the present results clearly demonstrate that activation of AMPA receptors inhibits PRL secretion in prepubertal rats. Furthermore, the increase in serum PRL concentrations $120 \mathrm{~min}$ after administration of $0.5 \mathrm{mg} / \mathrm{kg}$ NBQX in prepubertal females indicates that AMPA receptors have a physiological role in the control of PRL secretion at this age. The precise mechanisms involved in the inhibition of 
PRL secretion after activation of AMPA receptors remain to be elucidated but three possibilities can be considered: an inhibitory effect at the pituitary level, an increase in the release of dopamine, and/or a decrease in the secretion of hypothalamic PRL-releasing factors (PRFs). A direct action of AMPA at the pituitary level appears unlikely, as no significant responses were observed in vitro. Moreover, the divergent effects of AMPA on GH and PRL secretion (stimulatory and inhibitory respectively), despite the presence of a significant percentage of mammosomatotropes in prepubertal female pituitary (Shinkai et al. 1995), further suggest a hypothalamic (or supra-hypothalamic) primary site of action for the reported effects of AMPA. To analyze the involvement of dopamine in the inhibitory actions of AMPA on PRL secretion, we blocked dopaminergic receptors with domperidone prior to AMPA administration. In this experimental paradigm, AMPA was unable to decrease PRL secretion, suggesting that an increase in dopamine release might be involved in the inhibitory action of AMPA. These data are in line with results from experiments in male rats showing that pretreatment with $\alpha$-methyl-p-tyrosine (an inhibitor of DA biosynthesis) blocked the inhibitory effect of AMPA on PRL secretion (our unpublished results), and with our previous data showing that in prepubertal females activation of NMDA and KA receptors increased dopamine release, which in turn reduced prolactin secretion (Pinilla et al. 1996b, 1998). However, it has to be considered that, in our experimental model, removal of dopaminergic regulation resulted in a dramatic increase in PRL secretion, and thus the possibility remains that activation of AMPA receptors resulted, in addition, in decreased secretion of PRFs such as vasointestinal peptide, thyrotropin-releasing hormone or the newly characterized PRL-releasing peptide (Kato et al. 1978, Fagin \& Neill 1981, Hinuma et al. 1998). Assessment of the effects of AMPA on secretion of PRL-inhibitory and -stimulatory factors will shed further light on this matter.

A previous report indicated that AMPA receptors play a pivotal role in the generation of the LH surge in adult estrogen-primed ovariectomized rats (Ping et al. 1997). Present results showed, in contrast, that the basal function of the LHRH/gonadotropins axis in prepubertal females is AMPA-independent as it remained unaffected after administration of agonists and antagonists of AMPA receptors. Such discrepancies open up two possibilities: (1) AMPA receptors are involved in the control of $\mathrm{LH}$ surges, but not in the basal secretion of gonadotropins, and/or (2) the role of AMPA receptors in the control of LH secretion appears at or after puberty. In support of the latter, it has been shown that hypothalamic AMPA binding-sites increase at puberty (Zamorano et al. 1998) and estrogen up-regulates AMPA receptor levels in adult rat hypothalamus (Brann \& Mahesh 1997). Obviously, further experimental work is needed to clarify both hypotheses.
The role of NMDA and AMPA receptors in the control of LH secretion has been proven to be steroid-dependent. For example, central administration of NMDA and AMPA stimulated LH release in intact adult females, but was inhibitory in non-estrogen-primed ovariectomized rats (Brann \& Mahesh 1992b, Luderer et al. 1993, Ping et al. 1997). For this reason, we investigated whether ovariectomy affects the role of AMPA receptors in the control of anterior pituitary secretion in prepubertal females. Results obtained confirmed this hypothesis in three ways. First, the stimulatory effect of AMPA on GH secretion in prepubertal females was enhanced a week after ovariectomy. Secondly, the inhibitory effect of AMPA on PRL secretion was eliminated in prepubertal OVX females. Thirdly, AMPA inhibited and NBQX stimulated LH secretion in prepubertal OVX females, whereas both drugs were ineffective in intact females at this age. The mechanism(s) beyond these observations is, at present, unclear. The decrease in the inhibitory effect of AMPA on PRL secretion after ovariectomy may be related to estrogen deprivation, as estrogen has been shown to up-regulate AMPA receptor levels in adult rat hypothalamus (Brann \& Mahesh 1997). This mechanism, however, cannot account for the reported enhancement of $\mathrm{GH}$ response to AMPA in OVX female rats. Moreover, estradiol supplementation in OVX females prevented this effect (our unpublished observations). Studies on the differential regulation by ovarian steroids and peptides of the hypothalamic circuitry involved in the control of GH and PRL secretion are needed to elucidate the mechanism(s) for the reported effects of AMPA in OVX females.

In conclusion, these results demonstrate that activation of AMPA receptors stimulates GH, inhibits PRL secretion and has no effect on the LHRH/gonadotropin axis in prepubertal female rats. In addition, we provide evidence for a modulatory role of ovarian secretion on the actions of AMPA receptors at this age.

\section{Acknowledgements}

This work was subsidized by grants from DGICYT (Spain). The NIH supplied the radioimmunoassay materials for hormone determinations. We are indebted to Dr D González for LHRH determination and to Rocío Campón and Inmaculada Aguilar for their invaluable technical assistance.

\section{References}

Acs Z, Lonart G \& Makara GB 1990 Role of hypothalamic factors (growth hormone-releasing hormone and gamma-aminobutyric acid) in the regulation of growth hormone secretion in the neonatal and adult rat. Neuroendocrinology 52 156-160.

Bhat GK, Mahesh VB, Chu ZW, Chorich LP, Zamorano PL \& Brann DW 1995 Localization of the N-methyl-D-aspartate $\mathrm{R}_{1}$ receptor subunit in specific anterior pituitary hormone cell types of the female rat. Neuroendocrinology 62 178-186. 
Birge CA, Peake GT, Mariz IK \& Daughaday WH 1967 Radioimmunoassayable growth hormone in the rat pituitary gland: effects of age, sex and hormonal state. Endocrinology 81 195-204.

Bourguignon JP, Gerard A, Alvarez-Gonzalez ML \& Franchimont P 1992 Neuroendocrine control of onset of puberty: sequential reduction in activity of inhibitory and facilitatory N-methyl-Daspartate receptors. Journal of Clinical Investigation 90 1736-1744.

Brann DW \& Mahesh VB 1992a Excitatory amino acid neurotransmission: evidence for a role in neuroendocrine regulation. Trends in Endocrinology and Metabolism 3 122-126.

Brann DW \& Mahesh VB $1992 b$ Excitatory amino acid regulation of gonadotropin secretion: modulation by steroid hormones. Journal of Steroid Biochemistry and Molecular Biology 41 847-850.

Brann DW \& Mahesh VB 1994 Excitatory amino acids: function and significance in reproduction and neuroendocrine regulation. Frontiers in Neuroendocrinology 15 3-49.

Brann DW \& Mahesh VB 1997 Excitatory amino acids: evidence for a role in the control of reproduction and anterior pituitary secretion. Endocrine Reviews 18 678-700.

Collingridge GL \& Watkins JC 1994 The NMDA Receptor. Oxford: Oxford University Press.

Donoso AO, López FJ \& Negro-Vilar A 1990 Glutamate receptors of the non-N-methyl-D-aspartic acid type mediate the increase in luteinizing hormone-releasing hormone release by excitatory amino acids. Endocrinology 126 414-420.

Ebling FJP, Hui J, Mirakhur A, Maywood ES \& Hastings MH 1993 Photoperiod regulates the $\mathrm{LH}$ response to central glutamatergic stimulation in the male Syrian hamster. Journal of Neuroendocrinology 5 609-618.

Fagin KD \& Neill JD 1981 The effect of dopamine on thyrotrophin hormone-induced prolactin secretion in vitro. Endocrinology 109 1835-1840.

Gabriel SM, Rocancio JR \& Ruiz NS 1992 Growth hormone pulsatility and the endocrine milieu during sexual maturation in male and female rats. Neuroendocrinology 56 619-628.

González LC, Pinilla L, Tena-Sempere M \& Aguilar E 1999 Regulation of growth hormone secretion by AMPA receptors in infantile, prepubertal and adult male rats. Endocrinology 140 $1279-1284$.

Hinuma S, Habata Y, Fujii R, Kawamata Y, Hosoya M, Fukusumi S, Kitada C, Masuo Y, Asano T, Matsumoto H, Sekiguchi M, Kurokawa T, Nishimura O, Onda H \& Fujimo M 1998 A prolactin-releasing peptide in the brain. Nature 393 272-276.

Kato Y, Iwasaki Y, Iwasaki J, Abe H, Yanaihara N \& Imura H 1978 Prolactin release by vasoactive intestinal peptide in rats. Endocrinology 103 554-558.

Kiyama H, Sato K \& Tohyama M 1993 Characteristic localization of non-NMDA type glutamate receptor subunits in the rat pituitary gland. Molecular Brain Research 19 262-268.

Kumar V, Lincoln GA \& Tortonese DJ 1993 Effects of excitatory amino acid receptor agonists and antagonists on the secretion of melatonin, luteinizing hormone and prolactin in the ram. Journal of Neuroendocrinology 5 649-654.

López FJ, Donoso AO \& Negro-Vilar A 1990 Endogenous excitatory amino acid neurotransmission regulates the estradiol-induced LH surge in ovariectomized rats. Endocrinology 126 1771-1773.

Luderer U, Strobl FJ, Levine JE \& Schwartz NB 1993 Differential gonadotrophin responses to N-methyl-D,L-aspartate in metestrous, proestrous, and ovariectomized rats. Biology of Reproduction 48 857-866.

MacDonald MC \& Wilkinson M 1990 Peripubertal treatment with $\mathrm{N}$-methyl-D-aspartic acid or neonatally with monosodium glutamate accelerates sexual maturation in female rats, an effect reversed by MK801. Neuroendocrinology 52 143-149.

Mason GA, Bissette G \& Nemeroff CB 1983 Effects of excitotoxic amino acids on pituitary hormone secretion in the rat. Brain Research 289 366-369.
Meeker RB, Greenwood RS \& Hayward JN 1994 Glutamate receptors in the rat hypothalamus and pituitary. Endocrinology 134 621-629.

Müller EE \& Nisticó G 1989 Brain Messengers and the Pituitary. San Diego: Academic Press.

Ojeda SR \& Urbanski HF 1994 Puberty in the rat. In The Physiology of Reproduction pp 363-409. Eds E Knobil \& JD Neill. New York: Raven Press Ltd.

Ping L, Mahesh VB, Bhat GK \& Brann DW 1997 Regulation of gonadotropin-releasing hormone and luteinzing hormone secretion by AMPA receptors. Neuroendocrinology 66 246-253.

Pinilla L, Tena-Sempere M, González D \& Aguilar E 1995a Mechanisms of altered LH secretion in neonatally oestrogenized male rats. Journal of Endocrinology 147 43-50.

Pinilla L, Tena-Sempere M \& Aguilar E $1995 b$ The role of excitatory amino acid pathways in the control of pituitary function in neonatally oestrogenized male rats. Journal of Endocrinology 147 51-57.

Pinilla L, Tena-Sempere M, Gonzalez D \& Aguilar E 1996a Positive role of non-N-methyl-D-aspartate receptors in the control of growth hormone secretion in male rats. Journal of Endocrinological Investigation 19 353-358.

Pinilla L, Gonzalez D, Tena-Sempere M, Aguilar R \& Aguilar E 19966 Effects of N-methyl-D-aspartate and kainic acid on prolactin secretion in prepubertal female rats. European Journal of Endocrinology $135464-468$

Pinilla L, Tena-Sempere M, Aguilar R \& Aguilar E 1998 Effects of $\mathrm{N}$-methyl-D-aspartic acid and kainic acid on prolactin secretion in hyper- and hypoprolactinaemic conditions. European Journal of Endocrinology 138 460-466.

van den Pol A, Waurin J \& Dudek F 1990 Glutamate, the dominant excitatory transmitter in neuroendocrine regulation. Science $\mathbf{2 5 0}$ 1276-1278.

Shinkai T, Sakurai Y \& Ooka H 1995 Age-related changes in the numbers of mammotrophs, somatotrophs and mammosomatotrophs in the anterior pituitary gland of female rats: a flow cytometry study. Mechanisms of Ageing and Development 83 125-131.

Spergel DJ, Krsmanovic L, Stojilkovic S \& Catt K 1994 Glutamate modulates calcium and gonadotropin-releasing hormone secretion in immortalized hypothalamic GT1-7 neurons. Neuroendocrinology $\mathbf{5 9}$ 309-317.

Tena-Sempere M, Pinilla L \& Aguilar E 1995 A possible role for endogenous nitric oxide (NO) in kainic acid (KA)-induced growth hormone $(\mathrm{GH})$ release in prepubertal rats. Neuroendocrinology Letters 17 251-257.

Tena-Sempere M, Pinilla L, Gonzalez D \& Aguilar E 1996 Involvement of endogenous nitric oxide in the control of pituitary responsiveness to different elicitors of growth hormone release in prepubertal rats. Neuroendocrinology 64 146-152.

Urbanski HF \& Ojeda SR 1990 A role for N-methyl-D-aspartate (NMDA) receptors in the control of $\mathrm{LH}$ secretion and initiation of female puberty. Endocrinology 126 1774-1776.

Villalobos C, Nuñez L \& Garcia-Sancho J 1996 Functional glutamate receptors in a subpopulation of anterior pituitary cells. FASEB Journal 10 654-660.

Wenthold RJ \& Petraglia RS 1998 Non-N-methyl-D-aspartate (NMDA) glutamate receptors: molecular properties. Frontiers in Neurobiology 3 129-151.

Zamorano PL, Mahesh VB, De Sevilla L \& Brann DW 1998 Excitatory amino acid receptors and puberty. Steroids 63 268-270.

Zuo Z, Mahesh VB, Zamorano PL \& Brann DW 1996 Decreased gonadotropin-releasing hormone neurosecretory response to glutamate agonists in middle-aged female rats on proestrus afternoon: a possible role in reproductive ageing? Endocrinology 137 $2334-2338$

Received 15 December 1998

Revised manuscript received 15 February 1999 Accepted 20 April 1999 